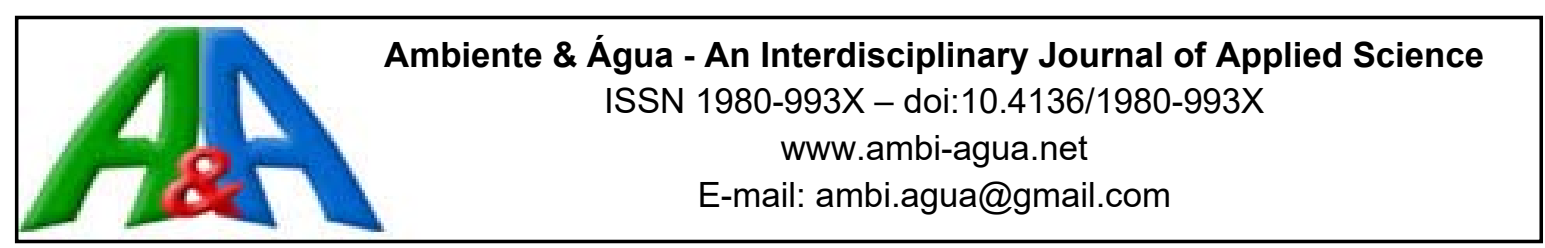

\title{
The use of caffeine as a chemical marker of domestic wastewater contamination in surface waters: seasonal and spatial variations in Teresópolis, Brazil
}

\author{
doi:10.4136/ambi-agua.1974
}

Received: 21 Jul. 2016; Accepted: 20 Dec. 2016

\author{
Eline Simões Gonçalves ${ }^{1 *}$; Silvana Vianna Rodrigues²; \\ Emmanoel Vieira da Silva-Filho ${ }^{3}$ \\ ${ }^{1}$ Fundação Oswaldo Cruz (FIOCRUZ), Rio de Janeiro, RJ, Brasil \\ Escola Nacional de Saúde Pública (ENSP) \\ ${ }^{2}$ Universidade Federal Fluminense (UFF), Niterói, RJ, Brasil \\ Departamento de Química Analítica \\ ${ }^{3}$ Universidade Federal Fluminense (UFF), Niterói, RJ, Brasil \\ Programa de Pós-Graduação em Geociências / Geoquímica Ambiental \\ *Autor correspondente: e-mail: elinesg@gmail.com, \\ silvana@vm.uff.br, emmanoelvieirasilvafilho@id.uff.br
}

\begin{abstract}
This study assessed the suitability of caffeine as an indicator for surface water pollution by domestic wastewaters. Caffeine concentrations determined in samples collected in the Paquequer River, located at the city of Teresópolis, a medium-sized city in the State of Rio de Janeiro, Brazil, were compared to other conventional water quality parameters such as phosphate, nitrate and ammonium concentrations to determine whether it as an efficient indicator of anthropic pollution of an urban aquatic environment. The Paquequer River originates in a pristine area called Parque Nacional da Serra dos Órgãos (PARNASO) and it crosses the urban area of the city of Teresópolis. Water samples were collected at seven points along the river, considering the periods of rain (summer) and drought (winter) and the different uses of land. Caffeine was measured using Solid Phase Extraction (SPE) and High Performance Liquid Chromatography (HPLC). Caffeine concentrations were found in a range from 0.16 to $47.5 \mu \mathrm{g} \mathrm{L}^{-1}$. The results show a positive relation between caffeine, phosphate, nitrate and ammonium concentrations and the increase of wastewater load, suggesting that caffeine can be used as an indicator of surface water pollution by domestic wastewaters.
\end{abstract}

Keywords: Anthropic contamination, caffeine, surface waters.

\section{O uso da cafeína como marcador químico de contaminação por esgoto doméstico em águas superficiais: variações sazonais e espaciais em Teresópolis, Brasil}

\section{RESUMO}

O uso da cafeína como um indicador para a poluição das águas superficiais por esgoto doméstico foi avaliado neste estudo. Concentrações de cafeína foram determinadas em amostras coletadas no rio Paquequer, localizado em Teresópolis, uma cidade de médio porte do Estado do Rio de Janeiro, Brasil, e foram comparadas com outros parâmetros convencionais de 
qualidade da água (fosfato, nitrato e amônio), de modo a caracterizá-la como um indicador eficaz da poluição antrópica do ambiente aquático urbano. O rio Paquequer nasce em uma área de preservação ambiental, o Parque Nacional da Serra dos Órgãos (PARNASO) e atravessa a área urbana da cidade de Teresópolis. Amostras foram coletadas em sete pontos ao longo do rio, considerando-se os períodos de chuva (verão) e seca (inverno) e os diferentes usos da terra. A cafeína foi determinada utilizando as técnicas de extração por fase sólida (SPE) e cromatografia líquida de alta eficiência (HPLC). As concentrações de cafeína foram encontradas numa faixa de $0,16-47,5 \mathrm{mg} \mathrm{L}^{-1}$. Os resultados mostram uma relação positiva entre as concentrações de cafeína, fosfato, nitrato e amônia, e o aumento da carga de esgoto, o que sugere que a cafeína pode ser utilizada como um possível indicador de contaminação por esgoto doméstico em águas superficiais.

Palavras-chave: Águas superficiais, cafeína, contaminação antrópica.

\section{INTRODUCTION}

From rivers to the coastal zone, continental aquatic systems are resources progressively used and transformed by humans via social and economic activity as a result of population growth, education, urbanization, industrialization, water engineering, and national and international environmental regulations (Meybeck, 2003). All of these factors can contribute to water pollution, particularly those related to population growth and inadequate disposal of sewage in water systems.

During the last decades, an increasing number of organic compounds have been detected in surface waters, generating great concern about pollution of this essential natural resource. Contaminated aquatic ecosystems can be a serious threat to human health and also to the environment. Some examples of water contamination on environmental health are pathogenic outbreaks such as diarrhea, the collapse of fisheries, decreased biodiversity, etc. (Myers et al., 2013). Consequently, protection of aquatic ecosystems is a major priority for humanity.

Domestic, industrial and agricultural sewage disposal into water streams are important causes of water pollution. In this context, the identification of the origin of pollution will play a key role in determining appropriate remedial measures. Such identification is accomplished through the use of a feasible marker. The ideal marker is one that is easily evaluated and that allows the unambiguous determination of the source and magnitude of contamination.

According to Bradley et al. (2007), an indicator applied to evaluate environmental contamination caused by humans ideally should be widely used, behave in the environment similarly to other major contaminants derived from domestic effluents, be present in relevant concentrations and detectable using available analytical methods and have an incomplete removal at wastewater treatment plants.

Traditionally, monitoring and tracking infiltrations of domestic wastewater in treated waters could be done by microbiological or chemical analyses. Microbiological analysis is conducted to investigate the presence of bacterial markers (like Escherichia coli), but there are disadvantages such as time-consuming analyses, limited source specificity (from animal, human or natural occurrences) and relatively short survival times in natural waters (Burge et al., 2003; Glassmeyer et al., 2005). Chemical determination is usually focused on nitrogen compounds such as ammonium, nitrate and nitrite. However, such analyses do not allow the identification of the origin of the pollution source (Sankararamakrishnan and Guo, 2005).

Owing to the recent development of analytical methods, several substances have been proposed as indicators of human contamination in urban water systems, such as caffeine, carbamazepine and sucralose. Caffeine is usually found in relatively high concentrations in 
waters streams and is easily measured. It has therefore been proposed as a potential wastewater tracer (Daneshvar et al., 2012; Spence, 2015).

The use of caffeine as indicator of sewage contamination is a relatively new analytical tool, especially when other indicators cannot reflect the source and magnitude of the observed contamination. Caffeine has a half-life of 30 days in natural environments, allowing its measurement in environmental samples even some time after initial contamination. Its behavior is more stable and conservative than that presented by others indicators, such as nitrogen, favoring the use of caffeine as a contamination indicator for domestic wastewater into surface waters.

Caffeine, (1,3,7-trimethylxanthine) is an alkaloid that occurs in more than 60 plant species and is ranked the number one drug worldwide, usually employed as a stimulant commonly found in coffee, tea, cacao, soft drinks and chocolate. It is also a component in hundreds of prescription and over-the-counter drugs, ranging from analgesics, to cold medicines, as a diuretic and as cardiac, cerebral and respiratory stimulant, and in "energy" dietary supplements (Burge et al., 2003; Gardinali and Zhao, 2002). Caffeine sources have claimed to improve endurance when included in athlete's diet and to increase the basal metabolic rate and caffeine is therefore classified by the International Olympic Committee (IOC) as a drug of abuse when it is present in human urine with concentrations higher than $12 \mu \mathrm{g} \mathrm{mL}^{-1}$ (Pesta et al., 2013).

The global average consumption of caffeine is about $70 \mathrm{mg}$ person $^{-1}$ day $^{-1}$ but varies in different countries (Chen et al., 2002). In Brazil, the average consumption is $171 \mathrm{mg} \mathrm{person}^{-1}$ day $^{-1}$, being coffee the main source of caffeine in the Brazilian diet (Camargo et al., 1999). Despite the fact that caffeine is extensively metabolized by humans with only approximately 3\% excreted unchanged in the urine (Tang-Liu et al., 1983), it is broadly found in the environment due to its continual introduction into the sewage system by the disposal of unconsumed coffee, tea or soft drinks down drains, and the rinsing of coffee pots and cups.

Caffeine is most likely to persist in the water column largely because of its high solubility $\left(13.5 \mathrm{~g} \mathrm{~L}^{-1}\right)$, low octanol-water partition coefficient $(\log \mathrm{Kow}=0.01)$ and negligible volatility. Additionally, caffeine is regularly and constantly consumed and discharged in sufficient quantities in wastewaters which allows easy analytical quantification. Its unequivocal anthropogenic origin with no potential biogenic sources make this substance a marker of choice since it complies with all prerequisites for a good tracer or anthropogenic marker of domestic contamination in natural waters (Daneshvar et al., 2012).

The environmental concentrations of caffeine range from "traces" to relatively high concentrations in influent wastewaters [up to $192 \mu \mathrm{g} \mathrm{L}-1$ (Gomez et al., 2007)]. In fact, several studies have reported the presence of caffeine in surface and ground waters across the world. It is common to find caffeine in effluent wastewater [0.07-126 $\mu \mathrm{g} \mathrm{L}^{-1}$ (Weigel et al., 2004)], in well water [1.7 $\mu \mathrm{g} \mathrm{L}^{-1}$ (Swartz et al., 2006)], in groundwater [0.23 $\mu \mathrm{g} \mathrm{L}^{-1}$ (Seiler et al., 1999)], in coastal waters [15-185 ng L-1 (Cantwell et al., 2016)] and surface water (112-781 ng L-1 [Daneshvar et al., 2012]). These studies show that caffeine can be easily found in aquatic environments.

In general, the determination of caffeine in environmental samples is taken concurrently with other target compounds by chromatographic multi-residue methods. In the majority of cases a solid-phase extraction step is applied in conjunction with High Pressure Liquid Chromatography (HPLC) and Gas Chromatography (GC) in order to allow detection of trace levels of the analytes in the samples. Chromatographic techniques (liquid or gas chromatography) using UV-Vis detector (as diode array detector - DAD) or mass spectrometry detector (MS) are the most used strategies (Cahill et al., 2004; Gardinali and Zhao, 2002; Ferreira, 2005; Verenitch et al., 2006). 
Teresópolis (Rio de Janeiro) was chosen to evaluate the applicability of caffeine as marker of water contamination caused by human activities, through the comparison between caffeine and other usual parameters of wastewater along the Paquequer River.

\section{MATERIALS AND METHODS}

\subsection{Study area and sampling sites}

The studied area was the Paquequer River located in the city of Teresópolis, a mountainous region of the State of Rio de Janeiro ( $870 \mathrm{~m}$ above the sea level), situated in the southeast region of Brazil. It has a drainage catchment of $269 \mathrm{~km}^{2}$ and its headwater is located in the Serra dos Órgãos National Park - PARNASO (22 $\left.26^{\prime} 58^{\prime \prime} \mathrm{S}, 42^{\circ} 59^{\prime} 08^{\prime \prime} \mathrm{W}\right)$ in a well-preserved Atlantic rain forest. The climate is super-humid tropical, with an annual average temperature of $18{ }^{\circ} \mathrm{C}$ and an annual precipitation between 1500 and $2500 \mathrm{~mm}$.

In its course, the Paquequer River crosses the urban area of the city of Teresópolis, with a population of approximately 125,000 inhabitants. The city of Teresópolis has no wastewater treatment plant, and so there are two ways to dispose of sewage: $35 \%$ of households use septic tanks or drains while in other households sewage is directly discharged into rivers through the rainwater drainage system $(\mathrm{CMN}, 2000)$. The Paquequer is the main water body receiving the majority of the urban runoff and sanitary effluents drained without any treatment from Teresópolis. Those characteristics make the basin of the Paquequer River an interesting area to evaluate the effectiveness of caffeine as an indicator of contamination by wastewater.

To conduct the study, seven sampling sites were chosen in the Paquequer River Basin, three located inside of a conservation area (one of them at the Beija-Flor Creek, a tributary of Paquequer River) and four other sites along the urban area of Teresópolis City (Figure 1). Water samples were collected on February $6^{\text {th }}$ (summer), March $27^{\text {th }}$ (beginning of spring) and October $4^{\text {th }}$ (end of winter) of 2007.

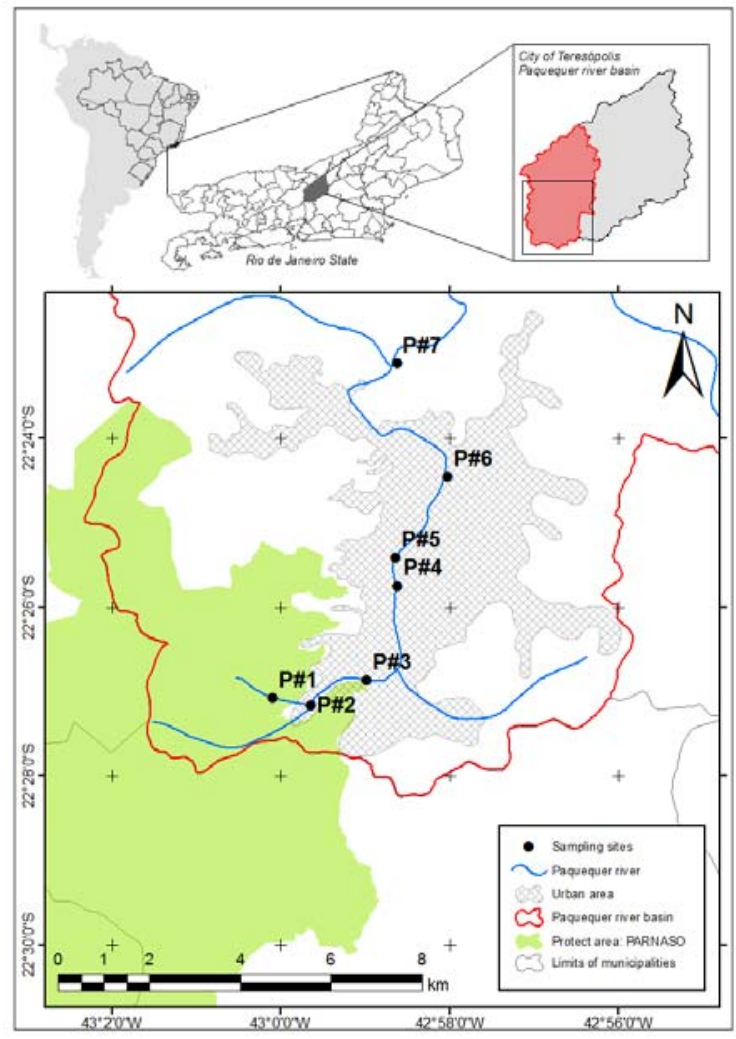

Figure 1. Location of the city of Teresópolis and the Paquequer River Basin. 


\subsection{Methodology}

\subsubsection{Sampling}

All samples for caffeine analysis were collected in duplicate in $1 \mathrm{~L}$ pre-cleaned amber glass bottles by submerging the sampling flasks approximately 10 centimetres below surface in the upstream direction. The samples were placed on ice, returned to the laboratory and stored in the dark at $<4^{\circ} \mathrm{C}$ until analysis, when they were not immediately filtered and extracted after arriving at the laboratory. Aliquots of filtered water samples were frozen for further analysis of nutrients.

The $\mathrm{pH}$ and conductivity were measured in situ using a calibrated portable conductivity meter (WTW) and a pH meter (Alfa Tecnoquímica), respectively.

\subsubsection{Nutrients analysis}

Nitrite, nitrate, ammonium, and phosphate were measured according to the Standard Methods (APHA et al., 2013). Ammonium was analysed by the indophenol's blue method. Nitrate was first reduced in a copper cadmium column and then analysed as nitrite. Nitrite was quantified by a reaction with sulfanilamide and $\mathrm{N}$-naphthyl ethylenediamine in an acid medium to form a diazo dye. Phosphate was measured by forming a complex with molybdate in an acid medium, reducing it with ascorbic acid. The absorbance of all samples was measured in a spectrophotometer at proper wavelength.

\subsubsection{Caffeine analysis}

The samples were filtered through a glass fiber filter with $0.7 \mu \mathrm{m}$ of porosity $(\mathrm{GF} / \mathrm{F}$, Whatman) to remove suspended matter and passed through a solid-phase extraction cartridge (SPE), using commercial Strata- $X^{\circledR}(500 \mathrm{mg}, 6 \mathrm{~mL}$ ) from Phenomenex (Torrence, CA), with the aid of a vacuum system at a flow rate of $3 \mathrm{~mL} \mathrm{~min}^{-1}$ (adapted from Burge et al., 2003).

Briefly, the cartridges were preconditioned with $6 \mathrm{~mL}$ of methanol and $6 \mathrm{~mL}$ of ultra-pure water (Millipore system). After the loading of samples, cartridges were dried under nitrogen for 1 hour and caffeine was recovered with $8 \mathrm{~mL}$ of methanol. The extracts were evaporated to dryness using a gentle stream of nitrogen. After reconstituting the samples to $500 \mu \mathrm{L}$ methanol:water $(30: 70, \mathrm{v} / \mathrm{v})$, analysis was performed. Procedural blanks were run periodically to check for caffeine contamination during extraction.

The determination of caffeine in the final extracts was carried out by High Pressure Liquid Chromatography (Bischoff Analysentechnik, Model 220) with detection by ultra-violet using a diode array detector (Shimadzu, model SPE-M104 VP) performed at $270 \mathrm{~nm}$. Chromatographic separation was accomplished using a Zorbax Eclipse ${ }^{\circledR}$ (Agilent, Model XDB C8, 4.6 x $150 \mathrm{~mm}$ I.D., $5 \mu \mathrm{m}$ ) column. The mobile phase was programmed to run isocratically with methanol: water $(30: 70, \mathrm{v} / \mathrm{v})$ at a flow-rate of $1 \mathrm{~mL} \mathrm{~min}^{-1}$.

Quantitative analyses were performed using external standards and the calibration graph was prepared for caffeine concentrations of $1.0 ; 2.5 ; 5,10.0 ; 20.0$ and $50.0 \mathrm{mg} \mathrm{L}^{-1}$. All standard solutions were prepared in methanol: water $(30: 70, \mathrm{v} / \mathrm{v})$.

The method detection limit (MDL) and the method quantification limit (MQL) for caffeine were determined by USEPA method EPA-821-R-03-005. Seven replicates of 1 L solution spiked with $0.15 \mu \mathrm{g} \mathrm{\textrm {L } ^ { - 1 }}$ caffeine were prepared and processed according to the same methodology applied to the real samples. The MDL was calculated by multiplying the standard deviation of the replicate analyses by the Student's $T$-value for 6 degrees of freedom at the $99 \%$ confidence level. The MQL was calculated by multiplying the standard deviation obtained in MDL calculations by 9 .

To evaluate the method recovery, simulated samples were prepared with ultrapure water and fortified with different concentrations of caffeine to final concentrations of $1,2.5,5,10,20$ and $50 \mu \mathrm{g} \mathrm{L}^{-1}$ (in duplicate to each concentration). These samples were processed according to

Rev. Ambient. Água vol. 12 n. 2 Taubaté - Mar. / Apr. 2017 
the same methodology applied to the real samples. The recoveries were calculated using the percentage formula: $(\% \mathrm{Rec})=[$ (observed concentration - blank concentration $) /$ (theoretical concentration)] $\mathrm{x} 100$.

\section{RESULTS AND DISCUSSION}

\subsection{Caffeine method performance}

Calibration curves were linear in the range of 0.1 to $50.0 \mathrm{mg} \mathrm{L}^{-1}$, with determination coefficients $\left(\mathrm{R}^{2}\right)$ higher than 0.999 . Recoveries ranged from $74.3 \%$ to $95.3 \%$, with a mean value of $85.7 \%( \pm 7.7)$. MDL and MQL, calculated at $0.15 \mu \mathrm{g} \mathrm{L}^{-1}$ standard solution was 0.05 and $0.15 \mu \mathrm{g} \mathrm{L}^{-1}$, respectively.

\subsection{Results overview}

The lowest caffeine concentrations were found in the samples collected inside the National Park (PARNASO) and the highest concentration was found along the urban area. Identical behavior was observed in the other parameters chosen to evaluate the water quality along the Paquequer River $\left(\mathrm{NO}_{3}{ }^{-}, \mathrm{NH}_{4}{ }^{+}, \mathrm{PO}_{4}{ }^{-3}\right.$ concentrations, $\mathrm{pH}$ and conductivity). In all samples, nitrite concentration was insignificant when compared to nitrate concentration. The results are presented in Table 1.

According to these results, caffeine concentrations in the basin of the Paquequer River ranged from $<0.15$ to $47.5 \mu \mathrm{g} \mathrm{L}^{-1}$ and during the studied period was (significantly) higher in Site \#6, the most anthropogenically impacted area among the seven sampling locations studied. This value is in agreement with other studies in some Brazilian rivers. Ferreira (2005), studying rivers of the drainage basin of Leopoldina (RJ), reported values from 60 to $357 \mu \mathrm{g} \mathrm{L}^{-1}$. Montagner and Jardim (2011) found caffeine concentrations from 0.2 to $73.9 \mu \mathrm{g} \mathrm{L}^{-1}$ in the Atibaia River, located in the region of Campinas (SP).

Table 1. Results found for water quality parameters in Paquequer River (Teresópolis/Brazil).

\begin{tabular}{|c|c|c|c|c|c|c|c|c|}
\hline Sites & & Period & $\begin{array}{c}\text { Caffeine } \\
\left(\mu \mathrm{g} \mathrm{L}^{-1}\right)\end{array}$ & $\begin{array}{c}\mathrm{NH}_{4}^{+} \\
\left(\mu \mathrm{mol} \mathrm{L}^{-1}\right)\end{array}$ & $\begin{array}{c}\mathrm{PO}_{4}^{-3} \\
\left(\mu \mathrm{mol} \mathrm{L}^{-1}\right)\end{array}$ & $\begin{array}{c}\mathrm{NO}_{3}^{-} \\
\left(\mu \mathrm{mol} \mathrm{L}^{-1}\right)\end{array}$ & $\begin{array}{c}\text { Cond } \\
\left(\mu \mathrm{S} \mathrm{cm}^{-1}\right)\end{array}$ & $\mathrm{pH}$ \\
\hline \multirow{8}{*}{ 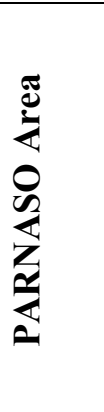 } & \multirow[t]{2}{*}{$\# 1$} & March $27^{\text {th }}$ & $<0.15$ & 8.52 & 0.06 & 0.62 & 9 & 6.62 \\
\hline & & Oct. $4^{\text {th }}$ & $<0.05$ & 4.80 & 0.26 & 0.91 & 11 & 7.35 \\
\hline & \multirow{3}{*}{$\# 2$} & Feb. $6^{\text {th }}$ & 0.21 & 12.08 & 0.15 & 12.20 & 5 & 6.65 \\
\hline & & $\operatorname{March} 27^{\text {th }}$ & 0.16 & 4.23 & 0.26 & 0.55 & 6 & 6.21 \\
\hline & & Oct. $4^{\text {th }}$ & $<0.15$ & 8.52 & 0.06 & 0.62 & 7 & 7.24 \\
\hline & \multirow{3}{*}{$\# 3$} & Feb. $6^{\text {th }}$ & 0.25 & 12.17 & 0.12 & 11.30 & 21 & 8.70 \\
\hline & & $\operatorname{March} 27^{\text {th }}$ & 0.17 & 7.86 & 0.10 & 8.60 & 17 & 7.86 \\
\hline & & Oct. $4^{\text {th }}$ & 0.17 & 4.80 & 0.31 & 8.10 & 18 & 7.70 \\
\hline \multirow{10}{*}{ 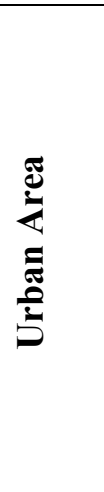 } & \multirow{2}{*}{$\# 4$} & March $27^{\text {th }}$ & 3.90 & 62.74 & 1.48 & 34.10 & 49 & 6.58 \\
\hline & & Oct. $4^{\text {th }}$ & 10.80 & 212.15 & 5.24 & 738.80 & 51 & 7.10 \\
\hline & \multirow{3}{*}{$\# 5$} & Feb. $6^{\text {th }}$ & 5.30 & 45.50 & 1.39 & 52.10 & 60 & 8.45 \\
\hline & & $\operatorname{March} 27^{\text {th }}$ & 5.50 & 8.62 & 3.26 & 44.00 & 83 & 7.10 \\
\hline & & Oct. $4^{\text {th }}$ & 7.97 & 260.63 & 6.99 & 610.60 & 60 & 6.86 \\
\hline & \multirow{3}{*}{ \#6 } & Feb. $6^{\text {th }}$ & 12.50 & 97.41 & 2.97 & 187.50 & 76 & 7.57 \\
\hline & & $\operatorname{March} 27^{\text {th }}$ & 22.50 & 277.56 & 9.65 & 31.60 & 114 & 6.92 \\
\hline & & Oct. $4^{\text {th }}$ & 47.50 & 567.70 & 17.46 & 2.77 & 105 & 6.74 \\
\hline & \multirow{2}{*}{$\# 7$} & March $27^{\text {th }}$ & 6.20 & 172.98 & 3.76 & 28.50 & 85 & 6.91 \\
\hline & & Oct. $4^{\text {th }}$ & 15.40 & 359.40 & 12.22 & 4.26 & 85 & 6.40 \\
\hline
\end{tabular}




\subsubsection{Protected Area: PARNASO Area}

At sample points $\mathrm{P} \# 1, \mathrm{P} \# 2, \mathrm{P} \# 3$, located inside the PARNASO, the concentration of caffeine was expected to be virtually zero or very close to the limit of quantification. In fact, this was observed during the dry season (winter) but not during the rainy season (summer) when higher concentrations were found. However, comparing the caffeine concentration found at PARNASO with the concentration of ammonia and phosphate measured at the same points, no significant correlation at $95 \%$ confidence (Pearson coefficient 0.78 and -0.63 for ammonia and phosphate, respectively for $\mathrm{n}=6$ ) was found, suggesting the existence of other caffeine sources different than the domestic waste at this region. The presence of caffeine in the local vegetation could be one reason for these results. In this case, during the rainy season caffeine could be transported from plants and contaminated soils to the streams. Similarly, Peeler et al. (2006) found caffeine at concentration of $14 \mathrm{ng} \mathrm{L}^{-1}$ in the samples of its background area and explained this result as originating from plants containing this alkaloid. Another possibility is air circulation. As Teresópolis is located close to the coast but behind high mountains where PARNASO is situated, atmospheric circulation could bring to PARNASO caffeinecontaminated air originating from roasting factories located in the city, contaminating the environment and the clouds and consequently the rain.

\subsubsection{Urban area}

Along the urban area of Teresópolis, the water quality of the Paquequer River suffers intense degradation, due mainly to the inadequate discharge of wastewater. It was therefore expected that caffeine, ammonia, phosphate and nitrate concentrations would increase along the river. This was observed for caffeine concentrations, ammonia and phosphate (points $\mathrm{P} \# 4$, $\mathrm{P} \# 5$, $\mathrm{P} \# 6$ ). However, at $\mathrm{P} \# 7$ these concentrations were lower than those found at $\mathrm{P} \# 6$. The reason for this concentration decrease is dilution, since between points $\mathrm{P} \# 6$ and $\mathrm{P} \# 7$ the river crosses a region with lower urban density and is joined by some smaller water bodies.

At the points $\mathrm{P} \# 4, \mathrm{P} \# 5, \mathrm{P} \# 6$ and $\mathrm{P} \# 7$, significant correlations (Pearson, $\mathrm{n}=10,95 \%$ confidence) between caffeine and both ammonia and phosphate ( $r=0.87$ and 0.89 , respectively) were observed. The strong correlations found between these parameters support the hypothesis that they originated from sewage discharge. No correlation between caffeine and nitrate was found in the samples collected at the urban area $(r=-0.22)$. Also, the correlations between nitrate concentration and all other parameters were not significant.

The nitrate concentrations do not show a continuous increase in the samples along the urban area. Higher concentrations at points $\mathrm{P} \# 6$ and P\#7 were expected, but they showed a significant decrease compared with points $\mathrm{P} \# 4$ and $\mathrm{P} \#$ 5. In campaign 3 , this reduction was even more pronounced than in campaign 2, where the values found in $\mathrm{P} \# 6$ and $\mathrm{P} \# 7$ are around 200 times smaller than in $\mathrm{P} \# 4$ and $\mathrm{P} \# 5$. These results demonstrate that the nitrate concentrations in the river Paquequer varied independently of the increase of sewage loading. This nutrient may have originated from the oxidation of other nitrogen compounds and may be rapidly incorporated by microorganisms along the river (McClain et al., 1998). In addition, there are various sources of nitrate, such as the application of fertilizers, which makes it even more limited as a pollution indicator for sewage contamination (Seiler et al., 1999).

An increment of two times the concentrations of caffeine, nitrate, ammonia and phosphate was observed when comparing the concentrations measured in the dry season with those of the rainy season. This was expected since the water volume of Paquequer River is strongly reduced during the dry season but the discharge of wastewater remains constant. Similar results were found in the study by Viviano et al. (2014).

In Brazil, water pollution observed in urban areas involves mainly the inappropriate discharge of domestic wastewater and waste disposal and demographic growth. It is very common to observe the dumping of wastewater effluents direct into the rivers, lakes and seas. 
As a result, in many regions of Brazil, wastewater is considered to be the major source of water pollution. Furthermore, water resources are vulnerable to contamination by local land uses and especially by waste disposal. In addition to fast population growth, the reliance on septic systems and cesspools for domestic wastewater disposal as well as the practice of discharging treated wastewater to surface water provide significant contamination.

\subsubsection{Comparison between found and expected caffeine concentration in the Paquequer River}

The Paquequer River acts as a surface water collection system for inputs of wastewater without treatment along the city traverse. In order to evaluate the relationship between caffeine consumption by the population and the values found in the Paquequer River, estimates were calculated based on the following considerations: $i$ - in 2007, the population of Teresópolis was of 150.268 inhabitants and $83 \%$ of this population (124,722 inhabitants) lives in the urban area (IBGE, 2007); ii- the wastewater produced by $23.28 \%$ of this population is directly into the Paquequer River (CNM, 2000); iii- the consumption of caffeine per person per day is $171 \mathrm{mg}$ day $^{-1}$ (Camargo et al., 1999); iv- the waste produced by each person is $0.16 \mathrm{~m}^{3}$ day $^{-1}$; and $v$ - the amount of caffeine excreted by the human body non-metabolized is of 1 to $6 \%$ of the total ingested (Chen et al., 2002). The results are shown in Table 2.

Table 2. Comparison between found and expected caffeine concentrations in the Paquequer River based on the population variables.

\begin{tabular}{|c|c|}
\hline Population Variables & Information \\
\hline Estimated urban population ( $83 \%$ of the total) & 124,722 habitants \\
\hline $\begin{array}{l}\text { Population whose wastewater is discharged directly } \\
\text { into the water body or other sewer }\end{array}$ & $23.28 \%$ \\
\hline Daily caffeine consumption per person & $171 \mathrm{mg} \mathrm{day}^{-1}$ \\
\hline $\begin{array}{l}\text { Percentage of caffeine unmetabolized and excreted per } \\
\text { person }\end{array}$ & $1-6 \%$ \\
\hline $\begin{array}{l}\text { Total excreted caffeine (unmetabolized) daily per } \\
\text { person }\end{array}$ & $1.71-10.26 \mathrm{mg} \mathrm{day}^{-1}$ \\
\hline Sewage volume produced daily per person & $0.16 \mathrm{~m}^{3}$ day $^{-1}$ \\
\hline $\begin{array}{l}\text { Total caffeine dumped through the sewage daily, } \\
\text { considering the percentage of the population of } 23.8 \%\end{array}$ & 49,650 a $297,899 \mathrm{mg}$ \\
\hline $\begin{array}{l}\text { Estimated daily sewage volume entering the } \\
\text { Paquequer River }\end{array}$ & $19,956 \mathrm{~m}^{3}$ day $^{-1}$ \\
\hline $\begin{array}{l}\text { Estimated caffeine concentration into the Paquequer } \\
\text { River }\end{array}$ & $10.69-64.12 \mu \mathrm{g} \mathrm{L}^{-1}$ \\
\hline $\begin{array}{l}\text { Caffeine concentration measured in the Paquequer } \\
\text { River in the urban área }\end{array}$ & $3.85-47.45 \mu \mathrm{g} \mathrm{L}^{-1}$ \\
\hline
\end{tabular}

Taking these conditions into consideration, we can calculate: $i$ - the amount of non-metabolized caffeine excreted by the human organism ranges from 1.71 to 
$10.6 \mathrm{mg} \mathrm{person}^{-1}$ day $^{-1}$; ii- a total of 49,650 to $297,899 \mathrm{mg}$ of caffeine is introduced into the Paquequer River every day in Teresópolis; $i i i-$ the volume of untreated waste produced daily is $19,956 \mathrm{~m}^{3}$ day $^{-1}$; and $v i$ - the concentration in the waters should range from 10.69 to $64.12 \mu \mathrm{g} \mathrm{L}^{-1}$. The calculated value is very close to that found in this work, which was from 3.85 a $47.45 \mu \mathrm{g} \mathrm{L}^{-1}$.

\section{CONCLUSIONS}

The results found in this work support the use of caffeine as marker of wastewater contamination of surface waters independent of weather conditions. Increasing of caffeine concentrations in the Paquequer River was observed in both the dry and rainy seasons. Additionally, the results are in concordance with those theoretically calculated for Teresópolis. This means the analytical methodology used in the study produced creditable results.

The concentrations of caffeine measured in the Paquequer waters correlated with those of ammonia and phosphate, but not with those of nitrate, indicated its superiority as indicator of water contamination due to domestic wastes other than nitrate.

The presence of caffeine in water samples collected inside the National Park, a pristine environment, and the absence of any correlation with caffeine concentrations and those of ammonia and /or phosphate, indicates the need for additional work to identify the origin of such contamination. Also, the sources of caffeine, its stability, chemical behavior and availability in tropical environments are matter of concern.

\section{ACKNOWLEDGMENTS}

The authors would like to thank the Brazilian National Research Council for financial support and Dr. Josino Costa Moreira for his suggestions.

\section{REFERENCES}

AMERICAN PUBLIC HEALTH ASSOCIATION - APHA; AMERICAN WATER WORKS ASSOCIATION - AWWA; WATER ENVIRONMENT FEDERATION - WEF. Standard methods for the examination of water and wastewater. $22^{\text {nd }}$ ed. Washington, 2013.

BURGE, I. J.; POIGER, T.; MULlER, M. D.; BUSER, H.-R. Caffeine, an anthropogenic marker for wastewater contamination of surface waters. Environmental Science \& Technology, v. 37, n. 10, p. 691-700, 2003.

BRADLEY, P. M.; BARBER, L. B.; KOLPIN, D. W.; MCMAHON, P. B.; CHAPELLE, F. H. Biotransformation of caffeine, cotinine, and nicotine in stream sediments: Implications for use as wastewater indicators. Environmental Toxicology and Chemistry, v. 26, n. 6, p. 1116-1121, 2007.

CAHILL, J. D.; FURLONG, E. T.; BURKEHARDT, M. R.; KOLPIN, D.; ANDERSON. L. G. Determination of pharmaceutical compounds in surface- and ground-water samples by solid phase extraction and high-performance liquid chromatography - electrospray ionization mass spectrometry. Journal of Chromatography A, v. 1041, p. 171-180, 2004.

CAMARGO, M. C. R.; TOLEDO, M. C. F.; FARAH, H. G. Caffeine daily intake from dietary sources in Brazil. Food Additives and Contaminants, v. 16, n. 2, p. 19-87, 1999. 
CANTWELL, M. G.; KATZ, D. R.; SULLIVAN, J. C.; BORCI, T.; CHEN, R. F. Caffeine in Boston Harbor past and present, assessing its utility as a tracer of wastewatercontamination in an urban estuary. Marine Pollution Bulletin, v. 108, n. 1-2, p. 321-324, 2016.

CHEN, Z.; PAVELIC, P.; DILLON, P.; NAIDU, R. Determination of caffeine as a tracer of sewage effluent in natural waters by on-line solid-phase extraction and liquid chromatography with diode-array detection. Water Research, v. 36, n. 19, p. 4830-4838, 2002.

CONFEDERAÇÃO NACIONAL DE MUNICÍPIOS - CNM. Infra-estrutura: esgotamento sanitário de Teresópolis/RJ. 2000. Available in:

http://portal.cnm.org.br/v4/v11/infra/mu_infra_esgotamento.asp?iIdMun=100133086. Access in: 27 jan. 2017.

DANESHVAR, A.; ABOULFADL, K.; VIGLINO, L; BROSÉUS, R.; SAUVÉ, S.; MADOUX-HUMERY, A.-S. et al.Evaluating pharmaceuticals and caffeine as indicator of fecal contamination in drinking water sources of the Greater Montreal region. Chemosphere, v. 88, n. 1, p. 131-139, 2012.

FERREIRA, A. P. Caffeine as an environmental indicator for assessing urban aquatic ecosystems, Cadernos Saúde Pública, v. 21, n. 6, p. 1884-92, 2005.

GARDINALI, P. R.; ZHAO, X. Trace determination of caffeine in surface water samples by liquid chromatography-atmospheric pressure chemical ionization-mass spectrometry (LC-APCI-MS). Environment International, v. 28, n. 6, p. 521-528, 2002.

GLASSMEYER, S. T.; FURLONG, E. T.; KOLPIN, D.W.; CAHILL, J. D.; ZAUGG, S. D.; WERNER, S. L. et al. Transport of chemical and microbial compounds from known wastewater discharges: Potential for use as indicators of human fecal contamination. Environmental Science \& Technology, v. 39, n. 13, p. 5157-5169, 2005.

GOMEZ, M. J.; MARTINEZ BUENO, M. J.; LACORTE, S.; FERNANDEZ-ALBA, A. R.; AGUERA, A. Pilot survey monitoring pharmaceuticals and related compounds in a sewage treatment plant located on the Mediterranean coast. Chemosphere, v. 66, n. 6, 993-1002, 2007.

INSTITUTO BRASILEIRO DE GEOGRAFIA E ESTATÍSTICA - IBGE. Censo Demográfico. 2007. Available in: http://www.ibge.gov.br. Access in: 10 jun. 2016.

MACCLAIN, M. E.; BILBY, R. E.; FRANK, J. T. Nutrient cycles and responses to disturbance. In: NAIMAN, R. J.; BILBY, R. E. (Ed.). River Ecology and Management. New York: Springer, 1998. 705p.

MEYBECK, M. Global analysis of river systems: from Earth system controls to Anthropocene syndromes. Philosophical Transactions of the Royal Society of London B, v. 358, n. 21, p. 1935-1955, 2003.

MYERS, S. S.; GAFFIKIN, L.; GOLDEN, C. D.; OSTFELD, R. S.; REDFORD, K. H.; RICKETTS, T. H. et al. Human health impacts of ecosystem alteration. Proceedings of the National Academy of Sciences of the United States of America, v. 110, n. 47, p. 18753-18760, 2013. 
MONTAGNER, C. C.; JARDIM, W. F. Spatial and seasonal variations of pharmaceuticals and endocrine disruptors in the Atibaia River, São Paulo State (Brazil). Journal of the Brazilian Chemical Society, v. 22, n. 8, 2011.

PEELER, K.; OPSAHL, S.; CHANTON, J. Tracking anthropogenic inputs using caffeine, indicator bacteria, and nutrients in rural freshwater and urban marine systems. Environmental Science \& Technology, v. 40, n. 24, p. 7616-7622, 2006.

PESTA, D. H.; ANGADI, S. S.; BURTSCHER, M.; ROBERTS, C. K. The effects of caffeine, nicotine, ethanol, and tetrahydrocannabinol on exercise performance. Nutrition \& Metabolism, v. 10, n. 71, p. 15, 2013.

SANKARARAMAKRISHNAN, N.; GUO, Q. Chemical tracers as indicator of human fecal coliforms at storm water outfalls. Environmental International, v. 31, n. 8, p. 1133$1140,2005$.

SEILER, R. L.; ZAUGG, S. D.; THOMAS, J. M.; HOWCROFT, D. L. Caffeine and pharmaceuticals as indicators of waste water contamination in wells. Groundwater, v. 37, n. 3, 405-410, 1999.

SPENCE, P. L. Using caffeine as a water quality indicator in the ambient monitoring program for Third Fork Creek Watershed, Durham, North Carolina. Environmental Health Insights, v. 9, suppl. 2, p. 29-34, 2015.

SWARTZ, C. H.; REDDY, S.; BENOTTI, M. J.; YIN, H. F.; BARBER, L. B.; BROWNAWELL, B. J. et al. Steroid estrogens, nonylphenol ethoxylate metabolites, and other wastewater contaminants in groundwater affected by a residential septic system on Cape Cod, MA. Environmental Science \& Technology, v. 40, n. 16, p. 4894-4902, 2006.

TANG-LIU, D.; WILLIAMS, R.; RIEGELMAN, S. Disposition of caffeine and its metabolites in man. Journal of Pharmacology and Experimental Therapeutics, v. 224, n. 1, 180$185,1983$.

VERENITCH S. S.; LOWE, C. J.; MAZUMDER, A. Determination of acidic drugs and caffeine in municipal wastewaters and receiving waters by gas chromatography - ion trap tandem mass spectrometry. Journal of Chromatography A, v. 1116, n. 1-2, p. 193-203, 2006.

VIVIANO, G.; SALERNO, F.; MANFREDI, E. C.; POLESELlO, S.; VALSECCHI, S.; TARTARI, G. Surrogate measures for providing high frequency estimates of total phosphorus concentrations in urban watersheds. Water Research, v. 64, p. 265-277, 2014.

WEIGEL, S.; BERGER, U.; JENSEN, E.; KALLENBORN, R.; THORESEN, H.; HÜHNERFUSS, H. Determination of selected pharmaceuticals and caffeine in sewage and seawater from Tromsø/Norway with emphasis on ibuprofen and its metabolites. Chemosphere, v. 56, n. 6, p. 583-592, 2004. http://dx.doi.org/10.1016/j.chemosphere.2004.04.015 